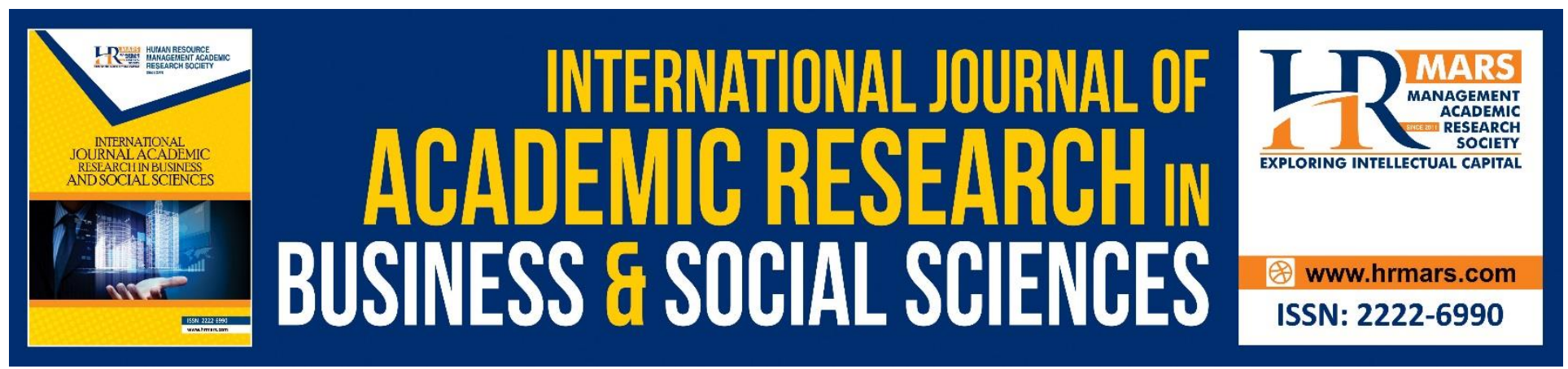

\title{
Is the Plate too Big for Malaysian SMEs to Implement HACCP?
}

Abd Razzif Abd Razak, Norzaidi Mohd Daud

To Link this Article: http://dx.doi.org/10.6007/IJARBSS/v10-i5/7426

DOI:10.6007/IJARBSS/v10-i5/7426

Received: 02 March 2020, Revised: 18 April 2020, Accepted: 29 May 2020

Published Online: 01 June 2020

In-Text Citation: (Razak \& Daud, 2020)

To Cite this Article: Razak, A. R. A., \& Daud, N. M. (2020). Is the Plate too Big for Malaysian SMEs to Implement HACCP? International Journal of Academic Research in Business and Social Sciences, 10(5), 1001-1007.

Copyright: (C) 2020 The Author(s)

Published by Human Resource Management Academic Research Society (www.hrmars.com)

This article is published under the Creative Commons Attribution (CC BY 4.0) license. Anyone may reproduce, distribute, translate and create derivative works of this article (for both commercial and non-commercial purposes), subject to full attribution to the original publication and authors. The full terms of this license may be seen

at: http://creativecommons.org/licences/by/4.0/legalcode

Vol. 10, No. 5, 2020, Pg. 1001 - 1007

Full Terms \& Conditions of access and use can be found at http://hrmars.com/index.php/pages/detail/publication-ethics 


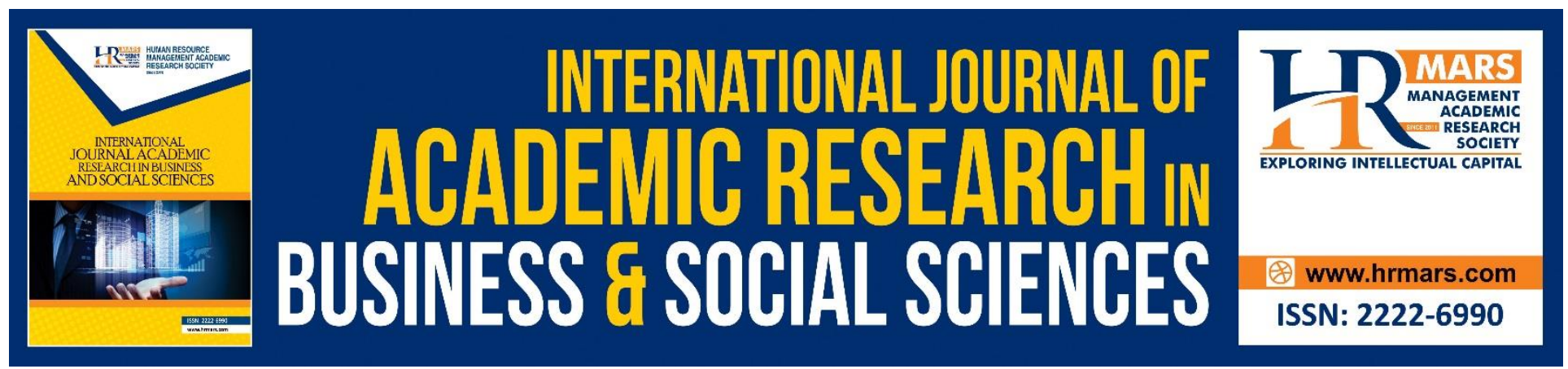

\title{
Is the Plate too Big for Malaysian SMEs to Implement HACCP?
}

\author{
Abd Razzif Abd Razak \\ Faculty Business Management, Universiti Teknologi MARA, Malaysia \\ Email: raziff23@yahoo.com \\ Norzaidi Mohd Daud \\ UiTM Press, Universiti Teknologi MARA, Malaysia \\ Email: norza544@uitm.edu.my
}

\begin{abstract}
Hazard Analysis Critical Control Point (HACCP) implementation represents the crucial element required for a country's competitiveness. Deducing from existing literature, it is undeniable that HACCP implementation will open new avenues to product quality, consumer protection, export opportunities and profit maximization. Despite scientific support of its principles for food safety, successful HACCP implementation has been limited among Small and Medium Enterprises (SMEs), particularly in Malaysia. Hence,this article addresses the issue of HACCP implementation among Malaysian SMEs with some highlight on the associated challenges. The challenges include insufficient technical resources, time, financial capability, knowledge and training. Lack of interest in the long term benefits of HACCP is also discussed. The paper reveals a summary of the challenges and benefits that Malaysian SMEs experience through successful HACCP implementation. Based on the comprehensive review of existing litera-ture, a suitable methodology for an empirical study in context of Malaysian SMEs is proposed. This study is expected to identify benefit and challenges for Malaysian SMEs to implement HACCP. As for recommendations, it is suggested that government agencies along with developmental organizations and other stakeholders should publish clear and detailed HACCP guidelines in Malaysia for its effective application.
\end{abstract}

Keywords: HACCP, SME, Benefit, Challenges, Malaysia.

\section{Introduction}

Countries are exercising mandatory restrictions on food safety standards to avoid imports (FAO, 2004; WTO, 2013). One such food safety standard recognized globally is the Hazard Analysis Critical Control Point (HACCP). It has been employed worldwide as a condition, which need to be fulfilled before food can be imported. The advantages of HACCP implementation include: a) Trade at competitive prices; b) Minimising wastage; c) Product reliability and d) Market growth (Herath \& 
INTERNATIONAL JOURNAL OF ACADEMIC RESEARCH IN BUSINESS AND SOCIAL SCIENCES Vol. 10, No. 5, May, 2020, E-ISSN: 2222-6990 ㄷ 2020 HRMARS

Henson, 2006; Scott, Wilcock, \& Kanetkar, 2009; Sarter, Sarter, \& Gilabert, 2010). In 2017, Malaysia's, food sector accounted for $10 \%$ of the country's output amounting to RM 21 billion, exporting to more than 200 countries (MIDA, 2018). Malaysia is further in a competitive position by pro-ducing Asian recipes that fulfill the expanding demand for specialty and ethnic foods (MIDA, 2018). These show that locally made Malaysian meals are emerging as a worldwide demand.

Investments in HACCP will increase the level of competitive advantage on global market, as it plays significant role in differentiating product quality by the consumers. Past research have analysed and found significant effect of HACCP certification on SMEs performance (Tarí \& Molina, 2002; Quazi \& Jacobs, 2004; Bayati \& Taghavi, 2007). HACCP benefits for SMEs include (but not limited to): (a) Improved Image in the market, (b) Product quality and (c) Competitive advantage. Three market patterns that could be held responsible for the selection of HACCP are: (a) Expanding supply chains, (b) Increasing business environ-ment impact and (c) Development of market requirements (Djordjevic, Cockalo, \& Bogetic, 2011; Escanciano \& Santos-Vijande, 2014).

Unfortunately, for developing countries, HACCP implementation still remains a challenge (Reardon \& Farina, 2001; Donovan, Caswell, \& Salay, 2001; Henson \& Loader, 2001). This is why SMEs' implementation of HACCP in Malaysia is constrained (Violaris, Bridges, \& Bridges, 2008; Ball, Wilcock, \& Aung, 2009; Fielding, Ellis, Clayton, \& Peters, 2011). Some of the major challenges for SMEs have been noted as lack of knowledge about the HACCP, financial limitations, time management and lack of focus (Yapp \& Fairman, 2006; Bas et al., 2007; Violaris et al., 2008). Hence based on the above, this article aims to review and forward a summary of the challenges and benefits that Malaysian SMEs experience through successful HACCP implementation. It is expected that apart from enriching the current literature, this article will create awareness about HACCP among Malaysian SMEs along with it benefit and challendes for implementation.

\section{Small and Medium Enterprises (SME) in Malaysia}

SMEs' commitment towards a country's development has a huge impact in achieving sustainable economic development (SME Corporation Malaysia, 2018). In ASEAN, SMEs comprise between $88 \%$ to $99 \%$ of all business entities, contributing significantly in creating new employment opportunities (ranging between 52\% to 97\%) (SME Corporation Malaysia, 2018). Particularly, SMEs engaged in exports related activities have helped their respective country's eco-nomic growth by improving GDP through higher economic productivity (Edwards, 1998 ; Jeffrey \& David, 1999 ; Noguer \& Siscart, 2005). In Malaysia, SMEs are defined categorically, as shown in Table 1 (SME Corporation Malaysia, 2018). 
INTERNATIONAL JOURNAL OF ACADEMIC RESEARCH IN BUSINESS AND SOCIAL SCIENCES Vol. 10, No. 5, May, 2020, E-ISSN: 2222-6990 @ 2020 HRMARS

Table 1.SME Definition in Malaysia

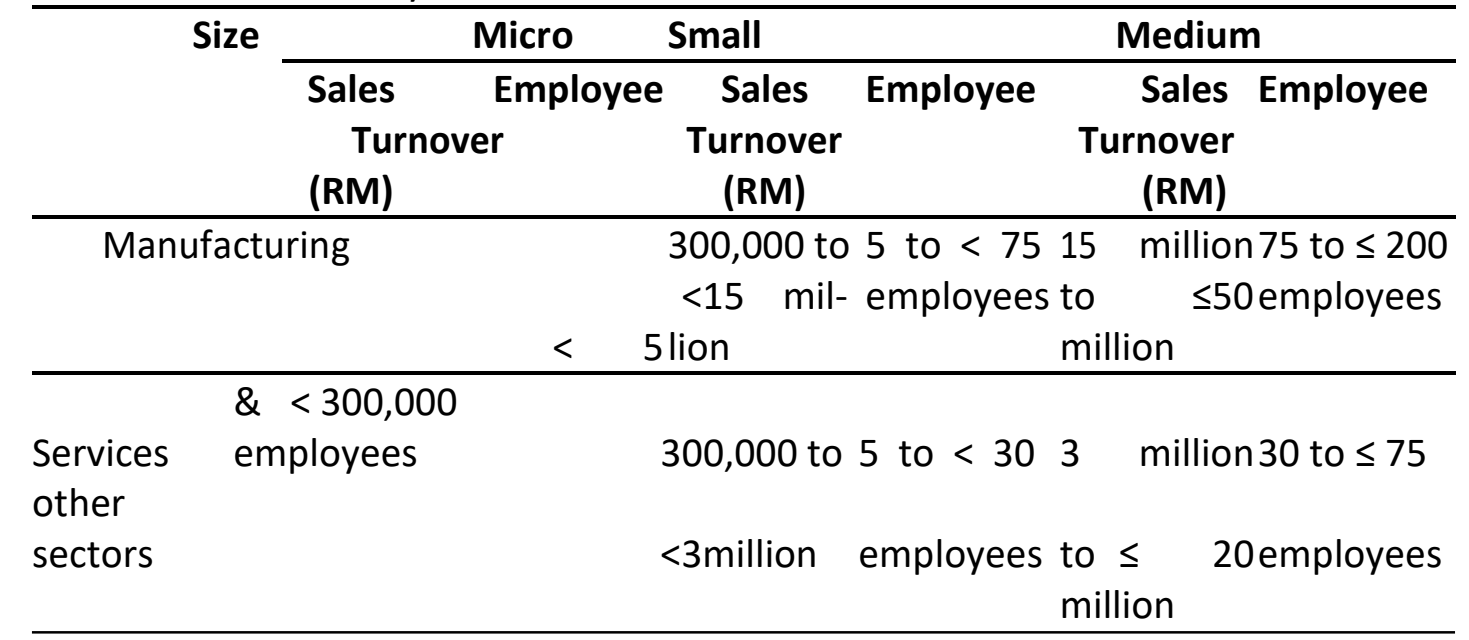

Source: SME Corporation Malaysia (2018)

SMEs in Malaysia had recorded a higher economic growth of $7.2 \%$ in 2017 as compared to $5.2 \%$ in 2016, thanks to the solid local demand and export activities that contributed both towards growth in employment and income (SME Corporation Malaysia, 2018). Positively upholding the favorable economic outlook, SMEs' Gross Domestic Product (GDP) growth is expected to expand at the low end of the projection range of $7 \%-8 \%$, given that Bank Negara Malaysia (BNM) has revised the overall GDP growth projection to 5\%, beneath the general GDP growth projection of $5.5 \%-6 \%$ in 2018 (SME Corporation Malaysia, 2018).

According to National Entrepreneurship Policy (DKN) (MED, 2019) which was being launched recently, whereby the main objective is to make Malaysia a successful entrepreneurial nation by 2030. The policy will work as a catalyst for Malaysia's achievement as a united, prosperous and dignified nation continue to build steadily with a more equitable and inclusive economic distribution. Five main objectives have been set out under the DKN: (1) To establish a holistic and conducive entrepreneurial ecosystem to support the development agenda Malaysia's socioeconomic inclusiveness, balance and stability ; (2) To establish a thoughtful and entrepreneurial Malaysian society ; (3) To increase the number of quality entrepreneurs, capable, resilient, global minded and competitive ; (4) Enhance the capabilities of micro, small and medium enterprises and cooperatives and (5) Making entrepreneurship a career of choice.

Considering global economic developments, current entrepreneurial achievements as well as internal issues and challenges entrepreneurial ecosystem in Malaysia, DKN has outlined six (6) Strategic Core. The strategies are: (1) Cultivate entrepreneurship in all societies ; (2) Optimizing the regulatory system and access to financing ; (3) Stimulate development integrated and holistic entrepre-neurship ; (4) Spur economic growth through innovative company ; (5) Improv-ing capability and performance Micro, Small and Medium Enterprises and (6) Internationalisation of High Growth Enterprises 
INTERNATIONAL JOURNAL OF ACADEMIC RESEARCH IN BUSINESS AND SOCIAL SCIENCES Vol. 10, No. 5, May, 2020, E-ISSN: 2222-6990 @ 2020 HRMARS

\section{Hazard Analysis Critical Control Point (HACCP)}

Pillsbury Corporation initiated the HACCP program following the interest of National Aeronautics and Space Administration (NASA) to guarantee food security (Bennet \& Steed, 1999; Nor, Jaliabc, \& Ghani, 2016). HACCP does not propose explicit moves, hence companies are allowed to select their own methods of controlling hazard (Caswell, 2003). HACCP guidelines are recognised by respective authorities worldwide (Reardon \& Farina, 2001). Perhaps this is the reason why every nation can adapt the HACCP in diverse and unique ways. In general, HACCP aims to reinforce the assurance of consumers using three major components: (a) Procedure, (b) Product and (c) Information (Caswell, 2003). Analysis of hazard is crucial to establish a mix of control measures, thereby ensuring effective food safety (Surak, 2007). Primarily, the HACCP Plan is found to include its specific seven main principles which include: (a) Identification of Hazards; (b) Determination of control measures; (c) Determination of Critical Control Points (CCPs); (d) Determination of critical limits for each CCP; (e) Determination of monitoring system for each CCP; $(f)$ Determination of corrective actions for each CCP and Determination of verification procedure (Department of Standard Malaysia, 2007).

The HACCP is not completely an independent system. It originates from prerequisite programs, such as Good Manufacturing Practices (GMP). For HACCP to be effective, these prerequisite programs need to be set up first (Department of Standard Malaysia, 2007). In Malaysia, The Malaysian Standard defines the prerequisite for food safety to guarantee the safety of food throughout preparation, storage, distribution and handling (Department of Standard Malaysia, 2007). It is prescribed that a HACCP team should have information about the products, processes and related hazards while documentation with regards to HACCP need to be reserved (Department of Standard Malaysia, 2007). Scott et al. (2009) further explained that motivational factors to implement HACCP include compliance with importing country's requirements. As HACCP mitigates the risks connected with the method of discovering hazaderous segments within food industry, it should be voluntarily taken up through the SMEs in the food industry of Malaysia. In order to effectively implement, SMEs are required to have sufficient knowledge about HACCP. Nevertheless, it is undeniable that SMEs with food safety knowledge have an advantage in implementing HACCP in their daily operation (Coleman, Griffith \& Botterill, 2000).

\section{Significance of HACCP to SMEs}

The significance of successful HACCP implementation for food safety along with the inadequate literature on the issue motivated this study to explore the issue of HACCP implementation among Malaysian SMEs, focusing on associated challenges and long term benefits of HACCP. This article is expected to contribute towards the policy makers by advocating that products with HACCP could boost exports, which eventually could increase national income. Meanwhile for SMEs, HACCP can act as an additional tool enabling them to improve their competency and productivity. As there is always room for educating experts, for both local and international consumers, HACCP could act as the best indicator to portray that specific food products are safe for human consumption.

\section{Conclusion}

HACCP implementation related challenges should not hinder SMEs' growth, as a cost to upgrade food safety systems. With adequate training, knowledge, and appropriate government support, SMEs and nations could witness economic progression. This requires an understanding of HACCP principles and 
commitment to it within the company. Therefore for SMEs to successfully implement HACCP, an effective HACCP team is required to prepare documents and training plans. As most SMEs have limited understanding of the HACCP, it is necessary that the governments clarify the goals of the strategy, and provide adequate information to ensure uniformity of HACCP. It should be convenient to plan activities with targeted SMEs with the aim of improving knowledge,understanding, and attitude to achieve business management that enhances food safety. The implementation of the HACCP represent the basic conditions for improving the competitive ability of those companies belonging to the food processing indutry, especially for SMEs who plan to venture into exporting activities. HACCP implementation in SMEs will ultimately provide stronger market orientation leading to product quality improvement, ensuring consumer protection while increasing profits simulteneously.

\section{Acknowledgement}

This research was supported by Federal Agricultural Marketing Authority (FAMA) Malaysia. We would like to thank our colleagues from Universiti Teknologi MARA who provided insight and expertise that greatly assisted the research. We are also immensely grateful to fellow research members for their comments on an earlier version of the article.

\section{Corresponding Author}

Norzaidi Mohd Daud

norza544@uitm.edu.my

UiTM Press, Universiti Teknologi MARA, Kompleks Usahawan,

Bangunan Fakulti Pengurusan Hotel dan Pelancongan,

40450 Shah Alam, Malaysia

\section{References}

Bennet, W. L., \& Steed, L. L. (1999). An integrated approach to food safety. Quality progress, 32, 3746.Bon, M., Hussain, M. (2010). Halal food and tourism: prospects and challenges. In: Scott, N., Jafari, J. (Eds.), Tourism in the Muslim World: Bridging Tourism Theory and Practice, vol. 2. Emerald Group Publishing, Bingley, pp. 47-59.

Caswell (2003). Food Safety in Food Security and Food Trade. Washington: International Food Policy Research Institute.

Department of Standard Malaysia. (2007). Food Safety According to Hazard Analysis and Critical Control Point (HACCP) System MS 1480 : 2007.

Djordjevic, Cockalo, \& Bogetic. (2011). An analysis of the HACCP system implementation- The factor of improving competitiveness in Serbian companies.

African Journal of Agricultural Research, 6(3), 515-520. https://doi.org/10.5897/AJAR10.889

Donovan, C., \& Salay, E. (2001). The Effect of Stricter Foreign Regulations on Food Safety Levels in Developing Countries: A Study of Brazil. Review of Agricultural Economics, 23(1), 163-175. https://doi.org/10.1111/1058-7195.00052

Edwards (1998). Openness, Growth Trade Liberalization , in Developing Countries.

Growth (Lakeland), 31(3), 1358-1393.

FAO. (2004). Worldwide Regulations for Mycotoxins in Food and Feed in 2003, Rome. Fielding, Ellis, Clayton, \& Peters. (2011). An evaluation of process specific information resources, aimed at 
INTERNATIONAL JOURNAL OF ACADEMIC RESEARCH IN BUSINESS AND SOCIAL SCIENCES

Vol. 10, No. 5, May, 2020, E-ISSN: 2222-6990 @ 2020 HRMARS

hazard analysis, in Small and Medium Enterprises in food manufacturing. Food Control, 22(8), 1171-1177. https://doi.org/10.1016/j.foodcont.2011.01.011

Jeffrey A. F., \& David, R. (1999). Does Trade Cause Growth ? The American Economic Review, 89(3), 379-399. https://doi.org/10.1257/aer.89.3.379

MED. (2019). National Entrepreneurship Policy Malaysia

MIDA. (2018). Food Industry in Malaysia. Food Technology and Resources Based Industries Division, MIDA. Retrieved from

http://www.mida.gov.my/home/administrator/system_files/modules/photo/uploads/2017 0906095028_SIB_Food Ind_Aug 2017_V4.pdf

Noguer, M., \& Siscart, M. (2005). Trade raises income: a precise and robust result.

(2016). Implementation of the hazard analysis and critical control point (HACCP) in Malaysia.

Journal of Engineering and Applied Sciences, 11(8), 1774-1778.Quazi, H. A., \& Jacobs, R. L. (2004). Impact of ISO 9000 certification on training and development activities: an exploratory study. International Journal of Quality \& Reliability Management, 21(5), 497517.

Reardon, T., \& Farina, E. (2001). The rise of private food quality and safety standards: illustrations from Brazil. The International Food and Agribusiness Management Review, 4(4), 413-421.

Sarter, S., Sarter, G., \& Gilabert, P. (2010). A Swot analysis of HACCP implementation in Madagascar. Food Control, 21(3), 253-259.Schumacker, \& Lomax. (2004). A Beginner's Guide to Structural Equation Modelling (2nd ed.). New Jersey: Lawrence Erlbaum Associates, Inc.

Scott, B. S., Wilcock, A. E., \& Kanetkar, V. (2009). A survey of structured continuous improvement programs in the Canadian food sector. Food control, 20(3), 209-217.

SME Colporation Malaysia. (2018). SME Report 2018.

Surak, J. G. (2007). A recipe for safe food: ISO 22000 and HACCP. Quality control and applied statistics, 53(4), 437-438.

WTO. (2013). Sanitary and Phytosanitary Measures.

http://www.wto.org/English/Tratop_e/Sps_e/Sps_e.Htm. 